\title{
Tracing Technological Pedagogical Content Knowledge (TPACK) on Practical EFL Teachers in Writing Context
}

\author{
St. Ayu Surayya ${ }^{1}$, Maman Asrobi ${ }^{2}$
}

Universitas Hamzanwadi ${ }^{1} \& 2$, Indonesia

Correspondence: St. Ayu Surayya, Universitas Hamzanwadi; Indonesia. e-mail: andreasurayya@gmail.com

Submitted: July 21, 2020

Revised: September 22, 2020

Accepted: October 02, 2020

DOI: $10.29408 /$ veles.v4i2.2417

URL: http://dx.doi.org/10.29408/veles. v4i2.2417

\begin{abstract}
With the world demand to provide digital school, this study examines how the integration among technology, pedagogy and content knowledge in writing context as the part of TPACK framework on the practical EFL teachers. The samples of this study are 27 of practical English teachers divided into three level of achiever (low, middle, and high). They were taking the Writing and Assessment courses as the part of their education to achieve the bachelor degree in Universitas Hamzanwadi, a private University in Lombok, Indonesia. This research took about six months of teaching and learning process. The observation and document results of the practical EFL teachers become the data primer of this study since the researchers act directly as the lecturer in the writing course. This study uses qualitative research as it investigates a process of teaching learning that lasted several months and happened in a particular setting. The result of study showed that the practical teachers' writing content and pedagogy knowledge were better than their technological knowledge. Furthermore, the high achievers of practical EFL teachers perform a good TPK and TCK rather than they who come from middle and low achiever.
\end{abstract}

Keywords: Pedagogical; Content; Technology; writing; TPACK

\section{Introduction}

Latter-day, technology becomes an important need influencing completely human life activity. The function of technology is changed from the optional tool for a specific work and industry being the trading media in education arena (Mishra \& Koehler, 2006; Warschauer \& Liaw, 2010).

Realizing this fact, recently the Indonesian government, appointed by Ministry of Education and Culture announced the digital school program that will be settled in 2025. As said by Cabinet Ministry of Education and Culture in the launching of Digital School Program in Jakarta (2019), digital school is a new penetration in educational world by employing information and technology development in all educational aspects. Even farther, this program is as the implementation of new learning for facing the 4.0 industrial revolutions. This new learning has student centred, collaborative work, information exchange, critical thinking, informed decision- 
making, and multimedia as the characteristics, which are suitable for 4.0 industrial revolutions where the emerging technologies have huge effect to educate people. On the other hand, technology also can be a solution in an unpredictably situation like nowadays pandemic.

Because of the important of technology, current education practitioner in Indonesia exuberantly suggests that teachers appropriately implement some forms of technology in their classrooms (Francis, 2017; Vassallo \& Warren, 2018). However, there is one basic step must passed up before reigning to implement technology in the teaching and learning process, which is examining the level of teachers' knowledge in technology.

Technological Pedagogical Content Knowledge (or TPACK for short) comes to answer the teachers' technological knowledge in a framework to produce effective teaching by emphasizing the connections among teachers' knowledge of content (CK), pedagogy (PK), and technology (TK) interact with one another (Spector et al., 2014) Mishra \& Koehler's (2006) create this formulation to escalate Shulman (2013) characterization of teacher knowledge, which is complete if it considers the role of technology knowledge.

In this framework, these three bodies of knowledge are extracted and influenced each other then create three new concepts, which are Pedagogical Content Knowledge (PCK), Technological Content Knowledge (PCK), and Technological Pedagogical Knowledge (TPK).

PCK describes the teachers' knowledge regarding on their learning on the specific course and how this course is presented pedagogically. As the connection between content and pedagogy, it seek the practicalities of a teaching and learning way to communicate the content effectively and make the students are understand the content easily, including curricula development, teaching method and media, student assessment, and reporting learning results (Harris et al., 2009). However, PCK framework is skipped in this study, since the researcher focuses on the implementation of technology.

Different with PCK, TCK often constrained the representational and functional capabilities of an optional technology. It is a theoretical framework defined by the one integration between technology and content. In educational field, it is the ability of considering which suitable technology used in order to presenting and learning a specific course (Slough et al., n.d.). As for TPK, it refers to an understanding of technology, which can support and afford specific pedagogical practicalities. TPK requires an understanding of pedagogical strategies applied including the way they present and review a general course to the use of certain technology (Margerum-Lzeys, 2002).

Furthermore, as the significant substance for research, TPACK has been already investigated in English Language Teach ing (ELT) context (Ekrem \& Recep, 2014; Ersanli, 2016; Köse, 2016) and also rapidly discussed in Indonesian context in recent years (Aniq et al., 2019; Ciptaningrum, 2017; Limbong, 2016). Most of the researches are unison focus on the practical EFL teachers' (abbreviated as PETs) perception or voices in facing the TPACK. Whereas, the research measuring the PETs competency was found in the study of Mahdum (2015) discussed about TPACK competency of PETs in Indonesia. The finding result of validity test through Pearson Correlation implied that the teachers have been able to develop and apply their TPACK well.

However, throughout those various researches about TPACK, there is limited research, 
which investigates about the PETs TPACK in limited scopes, for example, TPACK in reading, TPACK in listening, TPACK in speaking or TPACK in writing.

For teachers, especially English Second Language teacher, writing skill and technology has a firm relationship. Both of those fields have to be prepared since they are practicalities ESL teacher (PETs for short). As the crucial foundation for their life, writing and technology are not only used certainly in the years when the students still live in an academic atmosphere, but it is also needed for a their credible label in a working field. On the other hand, if the PETs are able to combine those field in their teaching, it will make them become ready to serve an effective teaching and learning for their own class latter. From these reasons, in this study, the researchers tend to focus in investigating PETs TPACK in their writing context

\section{Method}

\subsection{Participants}

The population of this study is a class from third until they came to the fourth semester of educational English students. This class was chosen because the researchers are assigned to teach this class and thus the sampling of the participants can be considered as convenient sampling (Nunan \& Bailey, 2009). From the perspective of classroom observation, this class was considered as a regular class, which was beneficial as it could lead to "a natural and undisturbed lesson" (van Lier, 1988, p. 39). There are 28 Indonesian students, 20 girls and 7 boys, aged between 19 until 21. They are originally from Sasaknesse ethnic group with Sasak language as their mother tongue, Bahasa Indonesia as their second language and English as their foreign language.

Because this study only focuses on the pre service teachers, thus the sample was selected from students who have a willingness to be an English teacher after they graduate. Finally, the researcher used an interview and observation to select single sample for low, intermediate, and high achiever of PETS. The determination of the low, intermediate and high achiever was based on the observation and students' writing result through the meetings.

\subsection{Data Collection}

\subsubsection{Instrument of Collecting Data}

The PETs were observed in 32 meeting or counted for a semester of writing class and a semester of assessment class, each of which lasted for 100 minutes, where "the teacher acts as researchers" (Stake, 1995). Field notes about what are said and done (van Lier, 1996) are written immediately in each meeting.

In order to answer the first question about PETs TCK, this study used the PETs' file on reporting and revising their essay by using Google Docs and WPS from the direct classroom teaching and learning process. Then, the answer of the second problem about the PETs' TPK was analyzed from the writing test made by the PETS by using assessment application that was found by the students themselves through the online assessment class.

\subsubsection{Techniques for Collecting Data}

In the middle semester of writing and assessment class, the students were informed of several matters below. First, the lecturer, apart from teaching, did research, implementing the 
TPACK framework, to find out the students' knowledge on the technology combining with the content and pedagogical knowledge. Then, after the PETS did all activities relevant to the TPACK framework and all the work over the course, including their drafts were submitted, some of PETs' works are included in the research report and published in an academic work, but their names were not disclosed.

Several rules were used in this data collection. For example, the research focused on three parts: how the PETs writing their expository text, making writing test, and scoring friends' text by using some technological application. Next, the students were free to advice another application for writing if they think Google Docs, WPS, Google Classroom and Google Form are difficult for them to be applied or they wanted to explore a new writing and assessment application. Last, file note and on file personal and group chat between researcher and PETs were also used to contribute the research analysis.

\subsection{Data Analysis}

The data were analyzed qualitatively after the PETs' works were collected. Several aspects describing the TK, CK, and PK in writing context was highlighted after the researchers saw the works. The data triangulation was used to make sure the validity of the conclusion.

\section{Results}

\subsection{Practical English Teachers' Technological Content Knowledge in Writing Context}

After the PETs did the writing task that are rewriting, revising, and adding some related idea to the given expository text, then the researchers put the PETs works in some criteria describing the their TCK. The clear division result can be showed in the figure below.

Figure 2 TCK of PETs in writing context

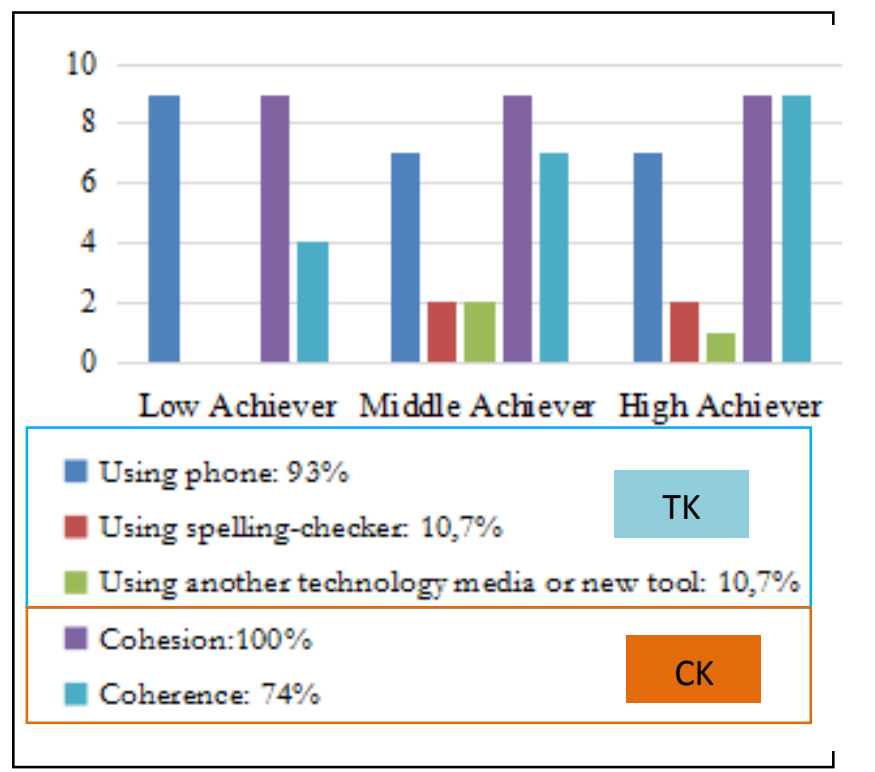

Following the new learning wave of cell phone, almost all of the PETs prefer to use cell phone to do their writing task (93\% of the PETs). Then, the control of technological 
knowledge is without mistyping words. It is as a warning signal to the PETs in its spelling check tool. The writing application both in computer or cell phone, such as WPS, Google docs and Microsoft word, concern about this criteria as the writing score. They make a spellcheckers to automatically highlight a spelling mistake or error and suggest possible spelling correction to users of word processors (Rimbar, 2017). In spell-checkers, the red underlines is as the sign of spelling errors and the green underlines is as the sign of grammatical errors. The writing application user can independently set their English spelling check by activating the tool. Surprisingly, even though most of the PETs utilized the cell phone, but only $10,7 \%$ of the PETs (4 PETs) are aware of their mistyping and totally revise it. From the 4 PETSs, only 1 of them who know how to check her task word spelling in cell phone and the rest of them use the computer to check their words spelling.

Likewise, the use another new innovative tool and media becomes the criteria of PETs' technological knowledge since it is the synthesis parameter of how the PETs integrate their daily knowledge of media and tool using with their learning activity. It is also show the PETs' initiative to find a new tool provided in the writing application. Yet, only used by three PETs or only $10.7 \%$. MA1 used a new template tool available in WPS to design her writing paper, then MA2 used a screenshot tool to report her writing application used. At the same part, HA1 preferred to upload and share her expository text in another media, Instagram.

On the other hand, the content knowledge of expository writing is based on two controls, there are cohesion and coherent. As a writing quality, cohesion is how a writing tying one and another explicitly or implicitly and the reader easily make the idea connection in text as its goal (Crossley et al., 2010). For example, the text used by HA10 (see Excerpt 1) has a coherence since there is relationships deal with text as a whole. The vocabulary choice in the text becomes the rope between a single paragraph with another. Moreover, HA8 gave a clear description about the text as a whole from the vocabulary used at the beginning paragraph. HA8 wrote, "here are some ways to improve your writing" as the control idea to the next two paragraphs. HA8 also did not release the first paragraph with her last paragraph by using the word "hard" in the first paragraph and using the word "difficult" in the last paragraph that has a same meaning and related it with the important of what she explained in the second and third paragraphs.

Next, the control on the $\mathrm{CK}$ is cohesion. It is the link between sentences words and phrases which are visible or easily understandable. For example, from the MA8's script, it shows some conjunctions indicating the semantics relationships between sentences and within sentences.

The relationship between sentences when MA8 used "there is one of example" relates good teacher with one of the prophet in Islam religion, Muhammad SAW. She also stated, "by setting this example of inclusion" to emphasis the rope between Muhammad SAW with the characteristic of how a good teacher attract the others. , and "like the hadith above" as the conjunction of example. Whereas, the conjunction of "but rather..." indicates the conjunction of comparison and "in conclusion" acts as the summary conjunction. 
Excerpt 1 HA8 writing task

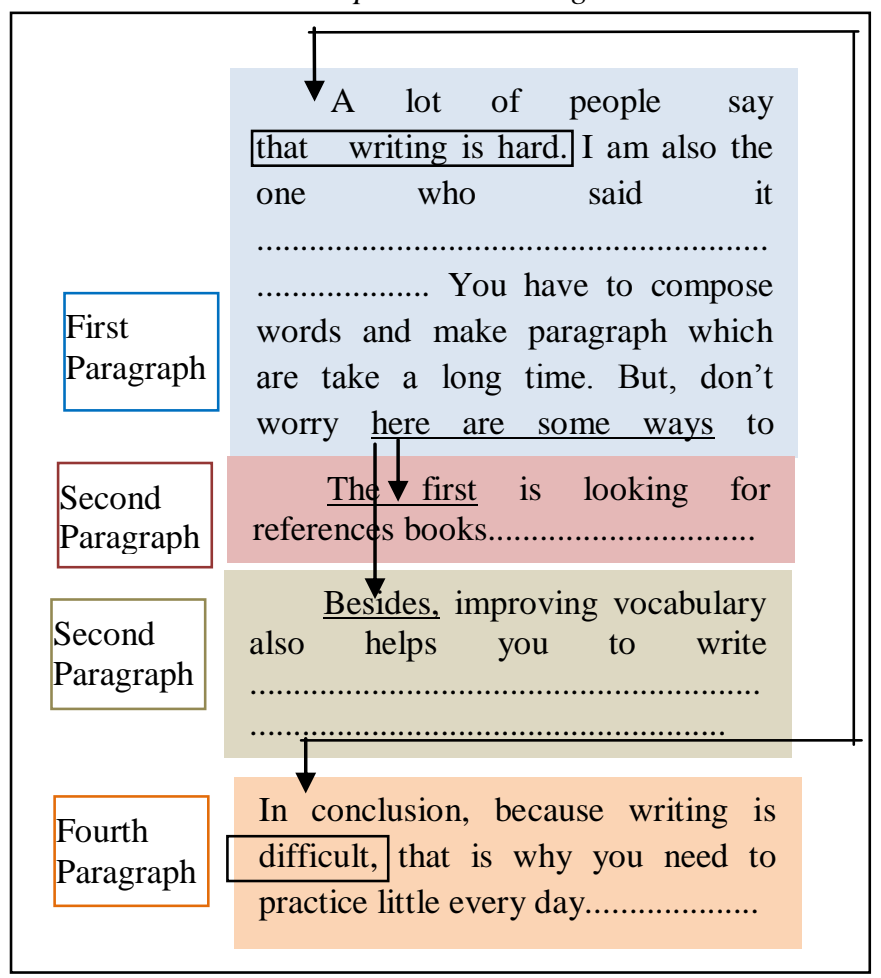

Then, the links within sentences in the PETs' writing text can are indicated in the using of some phrases. For example, the using of relative pronouns subordinating conjunction in "who shows", relative adjective as the subordinating conjunction in "that was", and concession as the subordinating conjunction in "even without" (see Excerpt 2).

If there is another sub-subchapter inside the subchapter the format writing of the subsubchapters is written in Capital letter for the initial letter and italic.

Excerpt 2 MA8 writing task

There is one of example a great teacher who
shows the truest religion with peace is prophet
Muhammad SAW. He never tough to exclude or expel
anyone from the religion of Islam. But rather
delivered a message that was all-inclusive to the
whole of mankind. The prophet Muhammad said: "By
Allah! If he may guide through you a single man to
Islam, it would be better for you than red camels".
(Al-Bukhari). By setting this example of inclusion,
Muslims have a tangible example of how to attract
others to the Islamic faith.
In conclusion, being a teacher is not only for a
professional, even without a bachelor's degree we can
become a teacher. Like the hadith above explains how
the prophet became a great teacher, we can imitate.....
…......................................................................................

\subsection{Practical English Teachers' Technological Pedagogical Knowledge}

To examine the PETs TPK, there were some aspects are illustrated in the graphic 
below.

Figure 3 TPK of PETs in writing context

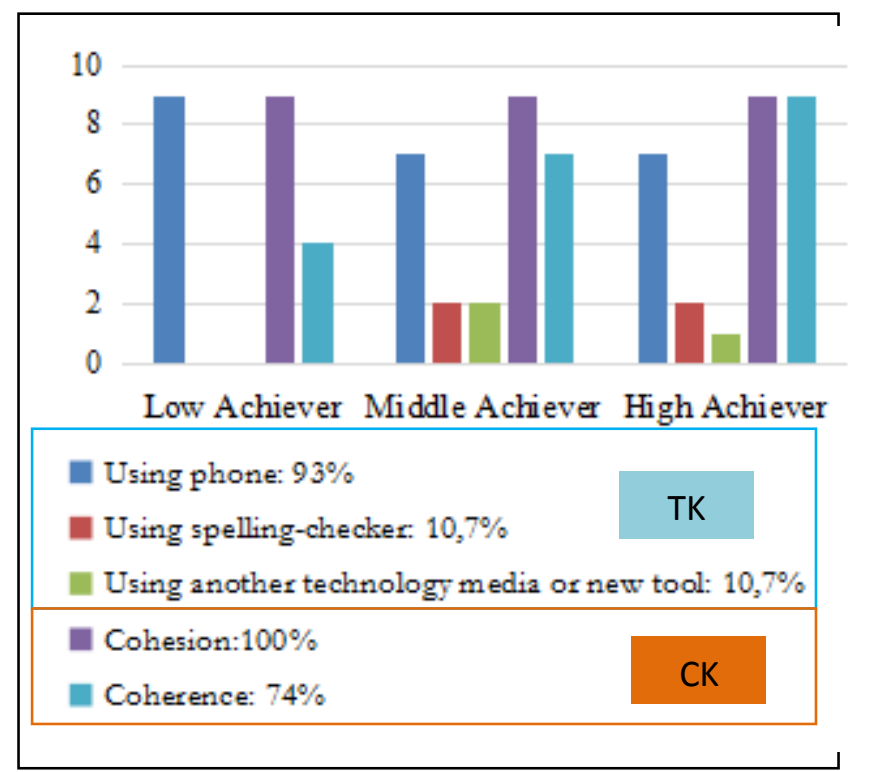

From the finding, 18,5\% of the PETS (all of them from the higher achiever level of PETs) gave clear instruction when made a test for their students. Besides giving a systematic instruction in doing their test, those PETs aware that writing is different with the other three skills in English language. It depends on the word amount, thus they made a word limitation by mentioning the minimum paragraph and word amount in their instruction.

Next, second aspect of pedagogical knowledge is when $44 \%$ of the PETs made a correct writing scoring. Five of the PETs are from the middle level achiever and six of them from high achiever level success created a scoring which is suitable for their students writing ability. Most of the PETS thought grammar, topic knowledge, text order, diction, and capitalization are important aspect in assess their students' writing test. However, no one from the low level are able to synthesize the content knowledge they got in writing course with the appropriate scoring they should write.

Then, ticking all the type of assessment used are about $70 \%$ spread evenly in all level of achiever. In this part, the researchers provided three options, whether their assessment refers to summative, interim or formative assessment in order to know if the PETs know how to tick their choice. But, one of the PETs who ticked a summative assessment gave an easy test for their students.

The other aspect to investigate the PETs technological knowledge is how the PETs uses a new scoring application. From the result, only $14.8 \%$ of them used Google Form scoring application and only $3.7 \%$ used Edomodo. The rest of them used a familiar Google Classroom which custom they take in their online class.

Last, only $33 \%$ of the PETs used a time limitation and all of them are they who applied Google Classroom application in their writing test. Yet, no one is able to use the time limitation in the Google Form. 


\section{Discussion}

Computer came to Indonesia at the beginning year of 2000. Then, now, PETs are used to do every study task by using a computer including writing task. But, from how $93 \%$ of the students prefer to use cell phone to write their expository text describes that the effectiveness of cell phone is able to deputize the position of computer nowadays. The PETs are success integrating the cell phone into all of parts of their life. They make the cell phone becomes the mandatory friends that can not be separated among university students (Balakrishnan \& Raj, 2011; Rahayuningsih et al., 2009) and it has a similar operating system to a traditional computer which also runs the advanced computing abilities of the complicated old computer.

Unhappily, even though the PETs following the new trend of applying cellphone into the educational writing purpose, but they are not maximal in exploring the application service. The PETs are not able to find the spelling-checker and also the new tool in their cell phone writing application. This condition is contrast with the PETs who write in computer perform a clear grammar and spelling mistake. This finding points out that the PETs are unskilled in developing and transferring what they always get in computer with the cell phone application. Thus, even though the PETs technological knowledge is visibly good, but it is just in the surface of an old technology, not in the new technology trend.

On the other hand, the finding shows that the CK of PETs is better than their TK. Most of the PETs in every level of achiever (low, middle and high) perform a good writing, both in their coherence and cohesion. This is because the PETs have already practiced a lot in their direct classroom writing by considering those two writing aspects. Expository text is also a familiar topic that has been told since they were in senior high school level. Such was the case, even though the data collected by offline class, but their writing knowledge about expository text and their knowledge of writing theory which are synthesized during the direct offline classroom create a satisfactory enough result in CK.

Furthermore, if reviewing the level of achiever, it can be seen that the level achiever walks straight on their level of knowledge. Most of the low achiever perform a lower CK rather than the middle and high achiever. Beside that, only middle and high achiever of PETs apply a new tool and media in writing. Those two points indicate that how PETs performs their TCK relies on the level of achiever. For the students in lower cognitive level, it becomes hard to control their TCK. Meanwhile, PETs in middle and high achiever easier to adopt and adapt a knowledge that newly they get rather than PETs in low achiever. Thus, this finding support the statement that only qualified PETs can operate the technology integrating with the other knowledge (Benešová \& Tupa, 2017) and the newest technology launched.

The new application tools and media integration are limited used by PETs in promoting their writing. It is as the sign of their minim technological knowledge because, in their writing class, they are only focus to learn their CK in creating the writing without preparing how and where the writing results would be performed technologically. They have a less motivation to integrate the technology because there is no a clear limitation of how important the technology to help their educational progress effectively. On the side of learners, this finding also indicates that PETs in Indonesia counted as passive learners who will only learn through guiding from the teachers. They will learn information if the teachers directly teach that 
information or if there is a formal instruction from the teacher to do the task. Instead of doing the task autonomously by finding the solution in the Google search, the PETs are intensive and periodically consult their understanding and confusion with the teachers. Only several PETs who have initiative to apply a new media and tool which the teacher never teach them before in the classroom-learning situation.

Next, the finding that only $18,5 \%$ of the PETs gave clear instruction when made a test for their students and only $44 \%$ of the PETs made a correct writing scoring indicate that the PETs pedagogical knowledge (PK) are still low. Different with objective type of assessment which is already acquainted with the PETs in grammar and reading session test since they were in school level, how to assess the writing is newly knew by them in this course. Meanwhile, writing assessment refers to subjective assessment, which needs a scoring rubric to avoid its subjectivity and this is newly known by them. On the other side, this research was also taken while the Covid-19 pandemic where all the teaching and learning have done by online. The online teaching situation definitely made the PETs had some difficulties in receiving the material.

Technology without any support from direct teaching and learning is difficult accepted by the PETs in Indonesia context. Some reasons such as internet quota, internet access or signals, and PETs activities become the obstacles in applying 100\% online teaching and learning. The demography aspect that $52 \%$ of the PETs are farmer and $31 \%$ are fisherman, small seller, and labourer made the PETs are busy helping their family business. Meanwhile, from the geography aspect, some of the PETs claimed that it was hard to find an internet access in their area. Thus, they have to climb a hill or go to a wide area like a farm to get an internet signal then are able to follow some explanations from the teacher.

A clear explanation was delivered to discuss the type of assessment. It makes $70 \%$ of the PETs tick the type of assessment in their writing test is as indication that the PETs have already known the purpose of their test. Furthermore, ticking the type of assessment is also as the indicator that the PETs knew how to practice a small tool of copy, paste, or insert a mark in both cell phone and laptop. They are able to integrate their TK of simple old writing procedure by using laptop with their TK of simple new writing procedure in cell phone. However, if the TK is still new and become more complete, the PETs were not adamantine to add their TK by themselves.

Google form and Edomodo is new technology assessment for the PETs. Only 14,8\% of the PETS used Google Form as their scoring application and only 3,7\% used Edomodo are the clarification that PETs preferred to apply an application which they are familiar with. In the months of covid-19, PETs were given some courses by their lecturers by Google classroom, but Google form were only introduced in two short tutorial videos. This is the reason why most of them are tend to use Google classroom for making writing assessment rather than to use a new application. Furthermore, the more intelligent the PETs, the more brave they are to try a new technology. But, the PETs who came from the middle and low lever achievement tend to avoid the challenging new technology. The condition where the PETs preferred to use the Google Classroom because they only got slightly information about how to operate a Google Form is analogously the Barak's (2017) statement that 
technology integration into teaching will be not effectively used if the PETs have lack knowledge about utilizing technology. This Barak's statement also in line with the finding that even tough the PETs choose the new application, but these PETs were not maximum in exploring all the tools that needed in their test. For example, how the PETs who uses Google Form in their writing test but do not use a time limiter provided by the Google Form.

It is known that Google form is counted as the free new assessment application for survey and questionnaire introduced by Google. Yet, as a new application, Google Form still need some inventions, included changing the layout not to be flat, adding some media and putting the time limiter automatically in the form field. Therefore, if the users want to apply some additional tools in their test form, they have to download it first. However, even though they knew that time limiter is important aspect for building the effective instruction of an assessment, the PETs still did not choose to implement time limiter in their writing test. They admitted that there is no tutorial about making a time limiter in the video from the teacher. Thus, merely introducing a technology in a glance is not enough for a teacher (Mishra \& Koehler, 2006), moreover the Indonesian students have a passive characteristic who always need the teachers' guidance and they will learn a new things if it becomes their task (Asrobi et al., 2019). This passive characteristic influences the PETs' eagerness to renew their knowledge, especially for them who from the low level achiever.

No one from the low level are able to synthesize the CK and PK in writing context as the prove that the low level of PETs need a special handling in their direct teaching and learning. They need a free and face-to-face access. Thus the teachers can easily see their expression whether they are still confused in absorb the course or not. How their not active respond in online discussion class also make it difficult to measure their understanding. This view gave an indirect finding that the technology is aimed to be the teacher's tool to develop CK (Akmal, 2017) but not become the full prominent beneficial tool used by the teacher to apply their PK in teaching and learning.

Finally, the integration of TCK and TPK in this study is contrast with Mahdum (2015). He found that the English teacher in Pekanbaru, Indonesia was good in their TPACK. Yet, the prove implying that the teachers were able to practice their TPACK well by Mahdum was still in general context. His study only investigated by a surface level questionnaire talking about how the teachers' view about their own knowledge and answered individually by the teachers without any deep interview or observation. As Halim, et al. (2018) stated that direct teaching and learning plays an important role in provided observation relaying on facts.

On the other hand, the questionnaire's topic asked by Mahdum (2015) is also general. For example, it asked about the teachers' view in their knowledge of general media used for teaching and learning process. It is different with discussed in this study which talking about the field of technology and assessment in writing context which is specifically investigated how the technology integrate effectively with the teachers' real job. When the teachers' TK are studied in the specific context, the integration of the technology knowledge with the pedagogy and content is still in the low level. It is inline the Terpstra's (2009) finding in Turgut (2017) that the level of Technological Knowledge on his research subjects were 
higher than their TPK. He also highlights that teachers cannot connect the TK in their teaching ability.

Indeed, several researchers have shown that nowadays technology lifestyle changes the monotonous classroom activity to be an active learning (Kompa, 2012 in Ciptaningrum (2017). The ubiquitous availability of technology media is also inserted in the traditional way of teaching and learning (A, 2019; Ekrem \& Recep, 2014). Yet, this active way of learning does not work with the teachers' in the middle and low level achiever which have a low technology knowledge in writing context.

Furthermore, in order to minimize this feebleness, a teacher must have an early additional knowledge of the technology implementation where the one way to add this knowledge is by giving a new form of how technology encompass their educational circumstance. Teachers need to know what the proper complex technology which is suitably used in the specific classroom course. Learning a specific technology for a specific course is very important in order to create the effective teaching and learning for both teachers and their learners. As found by Ekrem \& Recep (2014) in his research, observed that TPACK training programs supported the all information and technological PETs.

\section{Conclusion}

In the writing context, this article has presented that the PETs content knowledge (CK) are better than their PK, but the TK is the lowest between those three aspects. Furthermore, their PTK and TK depend on their level of achiever. For those who refer to low achiever, their TK and PTK are also low, meanwhile middle and high achievers have an average technological knowledge. Thus, this result gives a clear descriptive conclusion that the teachers in Lombok, Indonesia, have to encourage them selves to learn the new technology integration, specifically in the teaching and learning scope. Moreover, their passive characteristic and no willingness to find new knowledge by themselves, especially for those who from the middle and low level of achiever, make them need a direct guidance from the teachers.

As recommendation, PETs need to learn technology in their college course. Their need is not only based on the government program following the implementation of digital school or to face the unpredictable dangerous pandemic like the appearing of corona virus nowadays. More than those, adding the specific technological knowledge becomes the obligation of the PETs in order to give the students wish coin on the need of the up to date qualified teachers.

\section{References}

A, A. M. (2019). The use of technology in english language teaching. 2(3), 168-180. https://doi.org/10.22158/fet.v2n3p168

Akmal, A. (2017). Local culture and morality attachment to TPACK framework of preservice English teachers within the chalenge of the 21 st century skills. International Journal of Education, 9(2), 113. https://doi.org/10.17509/ije.v9i2.5465

Aniq, L. N., Drajati, N. A., Maret, U. S., \& Maret, U. S. (2019). Investigating efl teachers ' perceptions on their tpack development. 55(2010), 2013. 
Asrobi, M., Nazri, M. A., \& Hamzanwadi, U. (2019). Unsustainable english learning : the factors inhibiting retention of 'English as a foreign language ' (EFL) in an Indonesian University. 5(6), 304-313.

Balakrishnan, V., \& Raj, R. (2011). Exploring the relationship between urbanized Malaysian youth and their mobile phones: A quantitative approach. Telematics and Informatics, 29, 263-272. https://doi.org/10.1016/j.tele.2011.11.001

Barak, M. (2017). Science teacher education in the twenty-first century: A pedagogical framework for technology-integrated social constructivism. Research in Science Education, 47(2), 283-303. https://doi.org/10.1007/s11165-015-9501-y

Benešová, A., \& Tupa, J. (2017). Requirements for education and qualification of people in industry 4.0. Procedia Manufacturing, 11(6), 2195-2202. https://doi.org/10.1016/j.promfg.2017.07.366

Ciptaningrum, D. S. (2017). The development of the survey of technology use, teaching, and technology-related learning experiences among pre-service English language teachers in Indonesia. Journal of Foreign Languange Teaching and Learning, 2(2), 11-26.

Crossley, S., Mcnamara, D., Crossley, S. A., \& Mcnamara, D. S. (2010). UC Merced Proceedings of the Annual Meeting of the Cognitive Science Society Title Cohesion, Coherence, and Expert Evaluations of Writing Proficiency Cohesion, Coherence, and Expert Evaluations of Writing Proficiency. 32, 32.

Ekrem, S., \& Recep, C. (2014). Examining preservice EFL teachers' TPACK competencies in Turkey Solak Ekrem, Amasya University, Turkey Çakır Recep, Amasya, Turkey. Journal of Educators Online, 11(2), 1-22. https://eric.ed.gov/?id=EJ1033263

Ersanli, C. Y. (2016). Improving technological pedagogical content knowledge (TPACK) of Pre-Service English Language Teachers. International Education Studies, 9(5), 18. https://doi.org/10.5539/ies.v9n5p18

Francis, J. (2017). The effects of technology on student motivation and engagement in classroom-based learning. Technology On Student Motivation And Engagement In Classroom-Based Learning,

http://dune.une.edu/theseshttp://dune.une.edu/theses/121

Halim, S., Wahid, R., \& Halim, T. (2018). Classroom observation- a powerful tool for continuous professional development (Cpd). International Journal on Language, Research and Education Studies, 2(2), 162-168. https://doi.org/10.30575/2017/ijlres2018050801

Harris, J., Mishra, P., \& Koehler, M. (2009). Teachers' technological pedagogical content knowledge and learning activity types: curriculum-based technology integration reframed. Journal of Research on Technology in Education, 41, 393-416. https://doi.org/10.1080/15391523.2009.10782536

Köse, N. K. (2016). Technological pedagogical content knowledge (tpack) of English language instructors. Journal of Educational \& Instructional Studies in the World, 6(2), $12-19$.

http://www.wjeis.org/FileUpload/ds217232/File/02.naran_kayacan_kose...pdf\%0Ahttp:// ezproxy.gsu.edu/login?url=http://search.ebscohost.com/login.aspx?direct=true $\& \mathrm{db}=\mathrm{eue}$ 
$\& \mathrm{AN}=115577957 \&$ site $=$ eds-

live\%0Ahttp://content.ebscohost.com.ezproxy.gsu.edu/ContentServer.

Liamputtong, P. (2019). Qualitative Research Methods, 5th edition.

Limbong, E. (2016). The voices of preservice EFL teachers on the implementation of teacher educators،. IJEE (Indonesian Journal of English Education), 3, 171-191. https://doi.org/10.15408/ijee.v3i2.5511

Mahdum. (2015). Technological pedagogical and content knowledge (TPACK) of English teachers in Pekanbaru, Riau, Indonesia. Mediterranean Journal of Social Sciences, 6(5S1), 168-176. https://doi.org/10.5901/mjss.2015.v6n5s1p168

Margerum-Leys, J. (2002). Teacher knowledge of educational technology: A case study of student/mentor teacher pairs. Journal of Educational Computing Research, 26. https://doi.org/10.2190/JXBR-2G0G-1E4T-7T4M

Mishra, P., \& Koehler, M. (2006). Technological pedagogical content knowledge: A framework for teacher knowledge. Teachers College REcord, 108, 1017-1054. https://doi.org/10.1111/j.1467-9620.2006.00684.x

Rahayuningsih, R., Zede, V. A., Barat, R., \& Barat, J. (2009). The effect of handphone and learning motivation. 18, 69-72.

Rimbar, H. (2017). The influence of spell-checkers on students' ability to generate repairs of spelling errors. Journal of Nusantara Studies (JONUS), 2(1), 1. https://doi.org/10.24200/jonus.vol2iss1pp1-12

Sahin, I. (2011). Development of survey of technological pedagogical and content knowledge (TPACK). Turkish Online Journal of Educational Technology, 10(1), 97-105.

Shulman, L. (2013). Those who understand: Knowledge growth in teaching. Journal of Education, 193, 1-11. https://doi.org/10.1177/002205741319300302

Slough, S., Connell, M., \& Education, S. for I. T. and T. (n.d.). Defining technogogy and its natural corollary, technogogical content knowledge (TCK). International Conference; 17th, Society for Information Technology and Teacher Education, 2, 1053-1059. https://www.tib.eu/de/suchen/id/BLCP\%3ACN060335230

Spector, J. M., Merrill, M. D., Elen, J., \& Bishop, M. J. (2014). Handbook of research on educational communications and technology: Fourth edition. Handbook of Research on Educational Communications and Technology: Fourth Edition, 1-1005. https://doi.org/10.1007/978-1-4614-3185-5

Turgut, Y. (2017). Tracing preservice English language teachers' perceived TPACK in sophomore, junior, and senior levels. Cogent Education, 4(1). https://doi.org/10.1080/2331186X.2017.1368612

Vassallo, S., \& Warren, D. (2018). LSAC Annual Statistical Report 2017 Chapter 10 Use of technology in the classroom.

Warschauer, M., \& Liaw, M.-L. (2010). Emerging technologies in adult literacy and language education. National Institute for Literacy.

Yin., R. K. (1996). Case study research design and methods (5th ed.). Metodología de La Investigación, 28(March 2016), 61-103. https://doi.org/10.3138/CJPE.BR-240 
